Ciência e Natura, Santa Maria, v. 37 n.42 set-dez. 2015, p. 594-612

Revista do Centro de Ciências Naturais e Exatas - UFSM

ISSN impressa: 0100-8307 ISSN on-line: 2179-460X

\title{
A Urbanização na Zona Costeira: Processos Locais e Regionais e as \\ Transformações Ambientais - o caso do Litoral Norte do Estado do Rio Grande do
}

\author{
Sul, Brasil
}

\begin{abstract}
The Urbanization in the Coastal Zone: Local and Regional Processes and the Environmental Changes - the case of the North Coast of the Rio Grande do Sul State, Brazil
\end{abstract}
Nina Simone Vilaverde Moura ${ }^{1}$, Emilio Federico Moran'1, Tânia Marques Strohaecker ${ }^{1}$, Aline Vicente Kunst ${ }^{2}$

\author{
${ }^{1}$ Departamento de Geografia da Universidade Federal do Rio Grande do Sul, RS, Brasil. \\ 2 Programa de Pós-Graduação em Geografia da Universidade Federal do Rio Grande do Sul, RS, Brasil.
}

\begin{abstract}
Resumo
A urbanização ampliou a utilização dos recursos naturais do Litoral Norte do RS, comprometendo a sua qualidade ambiental e, por outro lado, possibilitou a diversificação econômica e sociocultural da região, contribuindo para o seu desenvolvimento. Neste sentido, a pesquisa busca compreender os problemas ambientais urbanos dos municípios do Litoral Norte com o intuito de contribuir com diretrizes para o desenvolvimento regional no marco da sustentabilidade. Para tanto foi necessário: (a) analisar os principais impactos ambientais do crescimento urbano em regiōes costeiras em diferentes escalas espaciais; b) caracterizar a região do Litoral Norte do Rio Grande do Sul, considerando as características naturais, históricas, populacionais, socioeconômicas e; c) identificar as principais alterações ambientais da região. O trabalho investigativo procura contemplar técnicas de análise e interpretação de caráter qualitativo e quantitativo, baseadas em fontes de dados primárias e secundárias. A região do Litoral Norte apresentou nos últimos anos transformações relevantes na sua dinâmica socioespacial determinadas, principalmente, pelas emancipações, urbanização e turismo sazonal. No entanto, essas transformações ocasionaram uma série de problemas para um ambiente caracterizado por ecossistemas diversificados e de grande suscetibilidade.
\end{abstract}

Palavras-chave: urbanização no Litoral Norte do Rio Grande do Sul; problemas ambientais; uso e ocupação do solo; indicadores socioeconômicos.

\section{Abstract}

Urbanization has expanded the use of natural resources along the North Coast of RS, undermining its environmental quality but, on the other hand, enabling the economic and socio-cultural diversity of the region that has contributed to its development. In this sense, this research seeks to understand the urban environmental problems of the North Coast municipalities in order to contribute to guidelines for regional development within a sustainability framework. This requires: (a) analyzing the main environmental impacts of urban growth in coastal regions at different spatial scales; b) characterizing the North Coast region of Rio Grande do Sul, considering its natural characteristics, historical, demographic, and socioeconomic features and; c) identifying the environmental changes in the region. The investigation searched for analytical techniques and qualitative and quantitative data both primary and secondary. The region of the North Coast has experienced in recent years significant changes in its socio-spatial dynamics determined mainly by subdividing existing municipalities into several, urbanization and seasonal tourism. However, these changes have caused a lot of problems for an environment characterized by diverse ecosystems and high susceptibility to erosion and degradation.

Keywords: urbanization of the Northern Coast of the State of Rio Grande do Sul, environmental problems, land use and land cover, social-economic indicators. 


\section{Introdução}

A urbanização na forma de construções ou áreas pavimentadas ocupam cerca de $0,5-2 \%$ da superfície da Terra, mas a taxa de crescimento é muito rápida. A cobertura urbana cresce, em média, mais que o dobro da taxa de crescimento da população urbana de acordo com Angel et al (2011). Provavelmente, esse rápido crescimento continuará nas próximas décadas, paralelamente, ao crescimento da população urbana e do crescimento econômico. A urbanização ocasiona alterações significativas na cobertura vegetal e no uso da terra, além dos limites das áreas urbanas, através de suas amplas redes de influência ou teleconecções urbanas. $O$ estilo de vida urbano aumenta as expectativas de consumo. Nos países centrais ou desenvolvidos, as aglomerações urbanas e extensos assentamentos periféricos fragmentam as paisagens rurais. Nos países periféricos ou menos desenvolvidos, a urbanização se sobrepõe a todos os outros usos da terra adjacentes à cidade, incluindo, principalmente, terras cultivadas por agricultura intensiva (Lambin e Meyfroidt, 2014).

O crescimento das aglomerações urbanas é uma tendência atual no desenvolvimento urbano global. Isso tem sido particularmente significativo ao longo das regiões costeiras em decorrência das suas vantagens de localização para as atividades industriais e comerciais. Mais de $50 \%$ da população mundial vive até cerca de $100 \mathrm{~km}$ da costa e oito das dez maiores cidades do mundo situam-se na região costeira, com altas taxas de crescimento em relação a outros países, segundo Chhabra et al (2006). Esse crescimento está relacionado à concentração populacional e às múltiplas atividades econômicas (incluindo o aumento do turismo).

A interação entre os processos naturais e as diferentes atividades humanas é crescente nas zonas costeiras, as quais são consideradas como área de transição entre a terra e $\mathrm{o}$ mar. $\mathrm{O}$ crescimento no número e no tamanho das cidades costeiras nos países de economia periférica tem provocado alterações na dinâmica dos fenômenos ambientais. Tais alterações estão acelerando os resultados das mudanças ambientais globais, as quais promovem modificações no comportamento e na frequência de eventos climáticos extremos e, nesse sentido, causam um estresse adicional ao sistema ambiental e humano. Tais sistemas são melhor compreendidos quando analisados de modo integrado, pois um distúrbio em um dos elementos de um sistema pode causar alterações no outro, através dos seus complexos mecanismos de integração (feedback), como por exemplo, a expansão urbana muitas vezes aumenta a impermeabilização da linha de costa, alterando o ciclo da erosão natural e dos movimentos de maré, os quais aumentam o risco de inundação, com consequências negativas à economia e ao bem estar da população (Bruns, 2013). Em tais situações, deve-se ter a preocupação de encontrar formas sustentáveis de crescimento urbano, nas quais os sistemas humanos e ambientais possam coexistir de maneira equilibrada.

O presente trabalho tem como objetivo geral caracterizar o uso e a ocupação do solo nos municípios do Litoral Norte do estado do Rio Grande do Sul, analisando os indicadores populacionais, socioeconômicos e as alterações ambientais decorrentes das diversas formas de apropriação da natureza. Como objetivos específicos, o estudo procura: a) analisar os principais impactos ambientais do crescimento urbano em regiões costeiras em diferentes escalas espaciais; b) caracterizar a região do Litoral Norte do Rio Grande do Sul, considerando as características naturais, históricas, populacionais, socioeconômicas e; c) identificar as principais alterações ambientais da região.

A Zona Costeira do Estado do Rio Grande do Sul caracteriza-se por apresentar uma planície sedimentar recente, do período Cenozóico, com variados ecossistemas de grande suscetibilidade. Essa paisagem, ainda em transformação, apresenta um conjunto de feições geomorfológicas sob condições de clima subtropical úmido costeiro em que se destacam as barreiras de dunas, os banhados, o cordão de lagoas e a escarpa do planalto, conferindo um cenário diferenciado no continente latinoamericano.

A região do Litoral Norte, um dos segmentos da Zona Costeira no Rio Grande do Sul, caracteriza-se pela sequência de ambientes longitudinais à costa, chegando até as escarpas do Planalto Meridional. Após a área de interface com o mar, identifica-se uma planície sedimentar 
costeira, composta por dunas, seguidas pelo cordão de lagoas litorâneas até o contato com a escarpa do Planalto Meridional, entalhada pelos vales dos rios Maquiné e Três Forquilhas.

A urbanização dos últimos cinquenta anos ampliou consideravelmente a utilização dos recursos naturais do Litoral Norte, o que tende a comprometer a sua qualidade ambiental. Por outro lado, a urbanização possibilitou a diversificação econômica e sociocultural da região, o que tende a contribuir para o seu desenvolvimento. Neste cenário, a Aglomeração Urbana do Litoral Norte do Rio Grande do Sul foi instituída em maio de 2004, através da Lei Complementar 12.100, com as seguintes funções públicas: saneamento, transporte público, turismo, planejamento do uso e da ocupação do solo urbano, preservação ambiental e organização territorial (Figura 1).

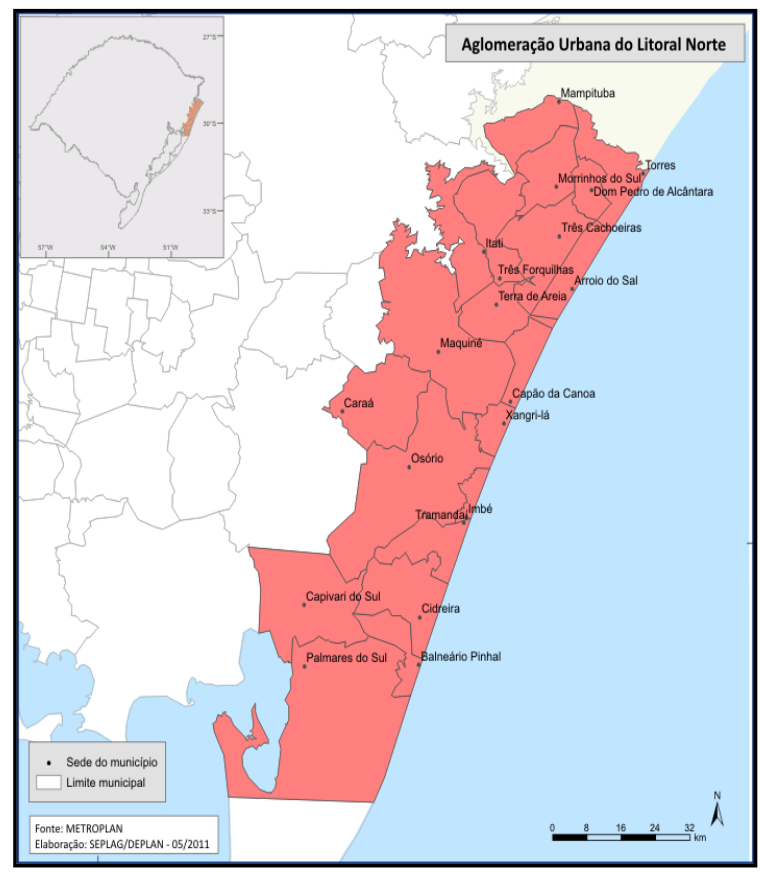

Figura 1: Aglomeração Urbana do Litoral Norte. Fonte: http://www.seplag.rs.gov.br/atlas/default.asp

A preocupação em estabelecer estratégias de planejamento e gestão da zona costeira brasileira tem início na década de 1980 com o Programa Nacional de Gerenciamento Costeiro (GERCO) instituído pela Comissão Interministerial dos Recursos do Mar (CIRM), no qual seis estados foram escolhidos para dar início à aplicação do programa: Rio Grande do Norte, Bahia, Rio de Janeiro, São Paulo, Santa Catarina e Rio Grande do Sul. Mais recentemente, o Ministério do Meio
Ambiente vem desenvolvendo outros projetos com o objetivo de preservar os ambientes costeiros e de atender às demandas relacionadas ao uso e a ocupação do solo. Entre outros, merece destaque, o Projeto Orla (Projeto de Gestão Integrada da Orla Marítima) que, em parceria com a Secretaria do Patrimônio da União (SPU), propõe o ordenamento do uso e da ocupação da orla marítima em nível municipal. No estado do Rio Grande do Sul, merece destaque a atuação do GERCO-RS que, juntamente com a Fundação Estadual de Proteção Ambiental Henrique Luiz Roessler (FEPAM), atua no gerenciamento costeiro, apoiado em ações de zoneamento, monitoramento, licenciamento e fiscalização dos ecossistemas e das populações locais, visando à preservação e à qualidade de vida da região costeira gaúcha.

Nesse contexto, esse trabalho poderá contribuir para o planejamento e a gestão pública dos municípios ao abordar alguns impactos ambientais que surgem em função das mudanças no uso e na ocupação da terra em diferentes ambientes naturais da região costeira em decorrência, principalmente, do aumento da urbanização e das atividades turísticas, bem como com relação às adaptações humanas diante das mudanças climáticas globais.

\section{Procedimentos Metodológicos e Operacionais}

O presente artigo procurou contemplar técnicas de coleta de informações, análise e interpretação de caráter qualitativo e quantitativo, baseadas em fontes de dados primárias e secundárias. O levantamento de dados secundários contempla pesquisa bibliográfica, cartográfica e por sensoriamento remoto. As informações de ordem primária referem-se a visitas a órgãos institucionais de governo e dos vários trabalhos de campo realizados entre os anos de 2002 a 2007 e, mais recentemente, entre os anos de 2010 a 2014 nos municípios do Litoral Norte do estado do Rio Grande do Sul.

A caracterização das unidades físico-naturais compreende uma análise dos principais compartimentos de relevo da região (topo e escarpa do Planalto Meridional, planícies lagunares e marinhas, cordões arenosos, áreas 
úmidas, entre outros) que foram identificados na área de estudo e no seu entorno, a partir das principais características geológicas, geomorfológicas, pedológicas e do Zoneamento Ecológico-Econômico (ZEE) desenvolvido pelo Programa de Gerenciamento Costeiro (Gerco) para o Litoral Norte do estado do Rio Grande do Sul.

A regionalização adotada, neste estudo, para o Litoral Norte, segue a proposta de Fujimoto et al (2006) e Strohaecker et al (2006), a qual procura contemplar a área física estabelecida pelo Programa de Gerenciamento Costeiro (Gerco) e os aspectos político-administrativos (divisão municipal), a partir da análise territorial dos processos emancipatórios e de urbanização, das migrações e de indicadores econômicos, contribuindo, assim, com elementos para subsidiar a formulação de políticas regionais e municipais. $\mathrm{O}$ levantamento e análises de dados, no período de 1950 a 2010, abrange um conjunto de 21 municípios, a saber: Arroio do Sal, Balneário Pinhal, Capão da Canoa, Capivari do Sul, Caraá, Cidreira, Dom Pedro de Alcântara, Imbé, Itati, Mampituba, Maquiné, Morrinhos do Sul, Osório, Palmares do Sul, Santo Antônio da Patrulha, Terra de Areia, Torres, Tramandaí, Três Cachoeiras, Três Forquilhas e Xangri-lá.

Os procedimentos metodológicos e operacionais da regionalização adotada contemplou a coleta de dados secundários em órgãos institucionais como o IBGE, a Fundação de Economia e Estatística do Estado (FEE-RS), a Assembléia Legislativa do Estado; revisão bibliográfica enfocando o processo emancipatório, a dinâmica espacial da população e levantamentos cartográficos. Dentro desse conjunto foram identificados quatro grupos distintos entre os 21 municípios, que são: municípios permanentes, urbanos para fins de segunda residência, municípios urbanos agroindustriais e municípios rurais. A diversidade de perfis de municípios neste estudo, dentro da unidade regional do Litoral Norte, tem o objetivo de salientar as similaridades e identidades do ponto de vista fisiográfico, econômico, demográfico e de urbanização, facilitando a gestão em nível municipal e regional.

Após a identificação dos quatro perfis de municípios, seguiram-se os trabalhos de campo para obtenção de informações relacionadas ao uso do solo e aos problemas ambientais. Para tanto, foram realizadas entrevistas com os moradores da região e visitas, previamente agendadas, nas prefeituras de quatro municípios (Torres, Capão da Canoa, Arroio do Sal, Capivari do Sul e Maquiné), sendo que cada município é representativo de um dos quatro perfis identificados no referido estudo de regionalização.

Os trabalhos de campo foram acompanhados de planilhas, previamente sistematizadas, para registrar o tipo de degradação ambiental em diferentes compartimentos de relevo (escarpa, planície, praia, dunas, banhados, etc.) decorrente de distintos usos do solo (orizicultura, hortifrutigranjeiros, pecuária, condomínios fechados, residências para a população permanente, área de mineração, entre outros.). As visitas agendadas junto às Prefeituras dos municípios foram fundamentais para identificar diferentes tipos de problemas ambientais, nem sempre detectados nas observações de campo.

Além disso, as informações quanto aos problemas ambientais foram obtidos a partir da bibliografia, em especial, trabalhos realizados no Litoral Norte na temática ambiental com enfoque nos recursos hídricos, qualidade das águas, desmatamento, extração mineral, extrativismo vegetal, entre outros estudos, em diferentes áreas do conhecimento (Geografia, Biologia, Hidrologia, etc.).

Por último, cabe destacar, que as observações de campo registradas, neste artigo, fazem parte de uma série de visitas realizadas desde 2003 a 2006 e, mais recentemente, entre 2013 a 2015.

\section{Resultados e Discussões}

\subsection{Consequências ambientais da urbanização costeira na América do Sul e no Brasil}

A América do Sul possui um grande número de bacias hidrográficas e áreas úmidas, as quais contribuem com nutrientes que sustentam a maior parte da produção primária de pescado da costa tropical e sub-tropical do continente americano. Muitos desses sistemas de drenagem são visivelmente alterados através das atividades 
humanas, ou seja, as mudanças no uso do solo, a poluição e as modificações nos cursos d'água são os prováveis responsáveis pelos grandes impactos costeiros no continente. As atividades que ocorrem no interior do continente tem considerável influência nas condições ambientais de muitas áreas costeiras na América do Sul. As maiores pressões antropogênicas são caracterizadas por dois grandes fenômenos: urbanização (como processo social) e as megacidades (como espacialização concentrada desse processo), ambos modificando diretamente as águas costeiras ou contribuindo para mudanças indiretas através das descargas de detritos urbanos no oceano.

Os principais e mais intensivos problemas ambientais costeiros da América do Sul são a poluição, a eutrofização e a alteração no equilíbrio entre erosão e sedimentação, de acordo com Salomons, Kremer e Turner (2005). Tais problemas causaram grandes impactos na zona costeira da América do Sul, resultando em alterações significativas em muitos ecossistemas.

A maioria dos poluentes envolve metais pesados provenientes das atividades industriais e agrícolas, carregados pela rede de drenagem até o oceano. A contaminação devido ao uso de pesticida na agricultura está afetando o rio Negro (Uruguai) e o sul do Brasil. Mesmo em regiões pouco alteradas como a Patagônia e o norte do Brasil, a concentração de metais pesados é muito alta em relação às referências (background) locais. A costa sudeste do Brasil e a Província de Buenos Aires são, provavelmente, as regiões mais afetadas pela eutrofização, devido à alta concentração populacional e industrial ao longo dos principais cursos d'água. Níveis de nutrientes medidos em, aproximadamente, 200 estações ao longo dos rios que drenam a região metropolitana do Rio de Janeiro mostram concentrações na ordem de até três vezes superior às referências (background) locais. Elevados níveis de coliformes fecais provenientes da rede de drenagem podem ser medidos em águas litorâneas e, mesmo em regiões com população esparsa, como a costa uruguaia, baixos níveis de oxigênio e alta concentração de nitrogênio podem ser observados (Lacerda et al, 2002).

Os desvios e represamentos dos cursos d'água estão causando sérias consequências no equilíbrio entre erosão e deposição ao longo de vários trechos da região costeira da América do Sul. As alterações na carga de sedimentos dos rios modificam a relação entre erosão e deposição, principalmente, em regiões estuarinas e deltaicas. Essas alterações tem causado assoreamento de manguezais (estuários no nordeste do Brasil); intensa erosão de manguezais (delta do rio Paraíba do Sul no sudeste do Brasil) e de praias arenosas (nordeste do Brasil e na costa da Província de Buenos Aires).

Conforme Lacerda et al (2002), a região costeira do Atlântico Sul do Brasil, Uruguai e Argentina é drenada por grandes rios como o Uruguai e o Paraná, bem como o Guaíba que deságua na maior laguna costeira do mundo, a Laguna dos Patos. A região metropolitana de Buenos Aires (Argentina) e a costa uruguaia do Rio de La Plata contém a maior concentração populacional e de atividades industriais ao sul das regiões metropolitanas de São Paulo e do Rio de Janeiro. A agricultura e a pecuária são as maiores atividades das bacias de drenagem que drenam esses grandes cursos d'água. As características e os problemas que esses três países dividem são um desafio à elaboração de um manejo integrado ao âmbito internacional.

A Zona Costeira do Brasil apresenta-se como uma parcela privilegiada dentro do imenso território da América do Sul quanto aos recursos naturais, econômicos e humanos, configurandose como um patrimônio nacional ${ }^{1}$. Os ecossistemas costeiros resultam da interação de ambientes marinhos e terrestres caracterizados por recortes litorâneos, pela diversidade biológica e fragilidade ambiental. A Zona Costeira brasileira sofre influência tanto de processos naturais quanto antrópicos, uma vez que nessa extensa e rica área vivem cerca de 50 milhões de pessoas em 17 estados, 478 municípios e 10 metrópoles (BRASIL, 2010).

${ }^{1}$ Conforme estabelece a Constituição Federal de 1988, em seu Título VIII, Capítulo VI, Artigo 225, Parágrafo 4⿳⺈, a Floresta Amazônica, a Serra do Mar, o Pantanal Mato-grossense e a Zona Costeira são considerados Patrimônio Nacional, ou seja, o conjunto de bens de uso comum, cujas características especiais lhe conferem posição especial, exigindo a preservação de suas condições básicas de existência. 
Conforme Moraes (1999), a ocupação dos municípios litorâneos no Brasil vem se intensificando nas últimas décadas decorrente de três vetores prioritários de desenvolvimento: a urbanização, a industrialização e a exploração turística. No caso da Zona Costeira do estado do Rio Grande do Sul, especificamente no segmento do Litoral Norte, os processos de urbanização e de exploração turística são os vetores mais representativos (Strohaecker, 2007).

\subsection{Caracterizações do Uso e da Ocupação da Terra nos Municípios do Litoral Norte do Rio Grande do Sul}

O estado do Rio Grande do Sul esteve submetido, nas últimas décadas, a um processo de emancipações municipais relativamente intensos quando comparado com outros estados e regiões brasileiras. O Litoral Norte do Rio Grande do Sul, seguindo a tendência estadual, passou por um processo relativamente recente de emancipações. Em 1965, os municípios de Santo Antônio da Patrulha, Osório, Torres e Tramandaí, a partir de seus limites político- administrativos, representavam, conjuntamente, o território do Litoral Norte considerado neste trabalho. Nas décadas seguintes, principalmente 1980 e 1990, surgem mais 17 novos municípios, os quais foram criados a partir de desmembramentos nos territórios dos municípios anteriormente citados. Atualmente, são 21 municípios que compõem a região do Litoral Norte. As emancipações desempenharam um papel fundamental no desenvolvimento da região e do estado de uma forma geral, tendo em vista os investimentos no setor rodoviário, no setor imobiliário, e as melhorias na infraestrutura (Figura 2).

No entanto, os dados de infraestrutura dos municípios do Litoral Norte do Rio Grande do Sul apontam deficiências no que diz respeito ao saneamento básico, coleta de resíduos sólidos, além de se observar um crescimento no número de moradias irregulares (favelas), principalmente nos municípios com maior número de população residente, e uma série de alterações ambientais decorrentes do processo recente de urbanização.

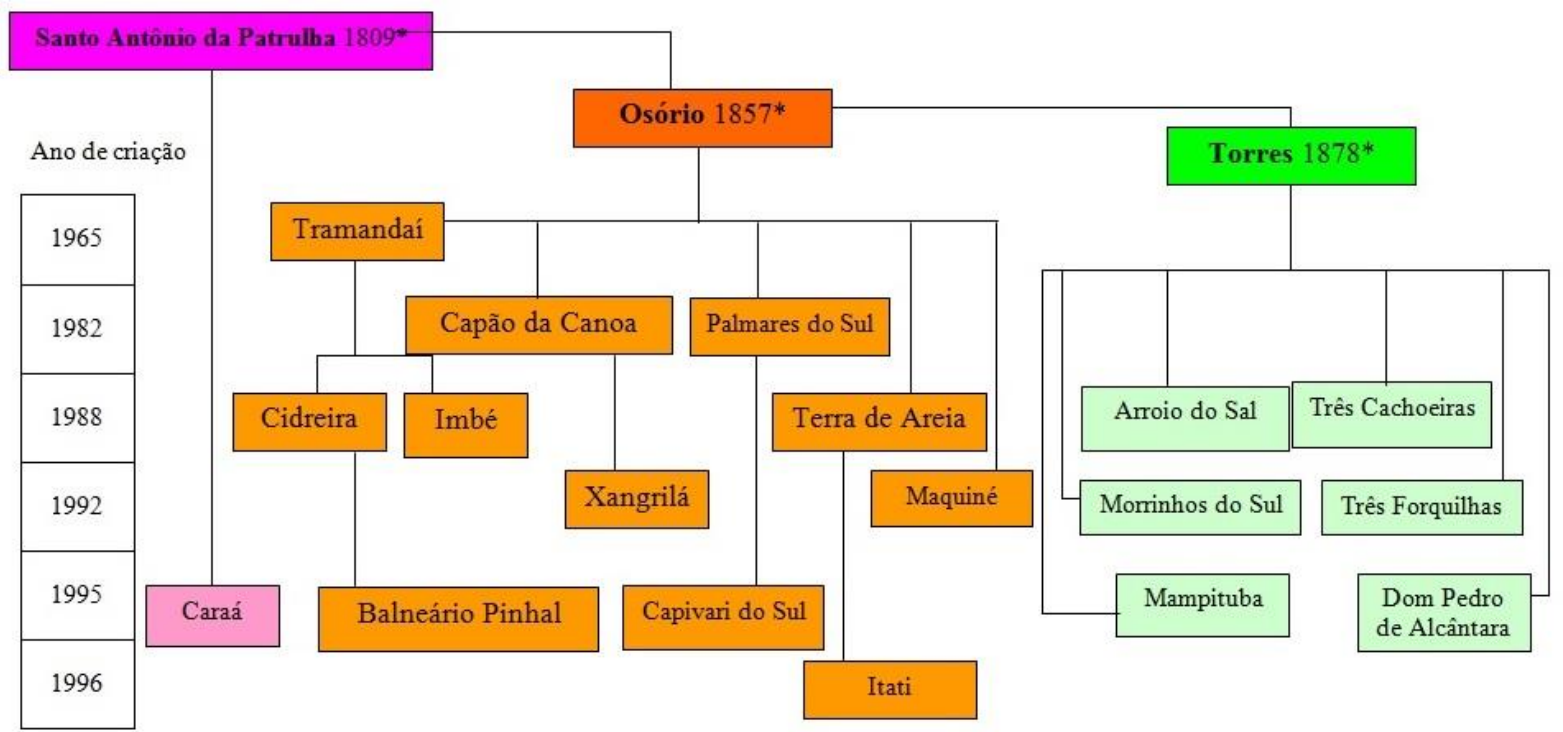

Figura 2: Diagrama da Evolução dos Municípios do Litoral Norte (1965-2002)

Fonte: Atlas da Evolução Municipal do Rio Grande do Sul (2000)

Informações verbais junto a Comissão de Assuntos Municipais da Assembleia Legislativa do RS.

*Ano de criação dos municípios-mãe.

Entre os anos de 1991 a 2000, o Litoral Norte apresentou o maior crescimento populacional, em termos relativos, no estado do Rio Grande do Sul, com uma taxa anual aproximada de 2,83\%.

Esse indicador é muito significativo se compararmos com as taxas anuais do estado
$(1,23 \%)$ e do Brasil $(1,64 \%)$, no mesmo período. Alguns municípios do Litoral Norte apresentaram taxas de crescimento anuais superiores a 5\%, como Balneário Pinhal $(7,56 \%)$, Cidreira (6,71\%), Arroio do Sal (6,41\%), Imbé (5,89\%), Capão da Canoa (5,16\%) e Xangri-lá 
(5,05\%) (RIO GRANDE DO SUL, 2002). Entre os anos de 2000 a 2010, a taxa anual de crescimento populacional no Litoral Norte foi de 2,05\%, ainda muito significativa em relação às taxas anuais de estado (0,49\%) e do Brasil (1,17\%) (RIO GRANDE DO SUL, 2014). Os municípios de Balneário Pinhal (3,83\%), Cidreira $(3,60 \%)$, Arroio do Sal (3,91\%), Imbé (3,74\%), Capão da Canoa (3,26\%) e Xangri-lá (4,23\%) permaneceram com elevadas taxas de crescimento populacional (IBGE, 2010)(Tabela 1).

A partir da análise realizada por Fujimoto et al (2005), Strohaecker et al (2006) e Fujimoto et al (2006), os 21 municípios do Litoral Norte do Rio Grande do Sul foram classificados em quatro perfis distintos, que são: municípios permanentes, urbanos para fins de segunda residência, municípios urbanos agroindustriais e municípios rurais (Figura 3).

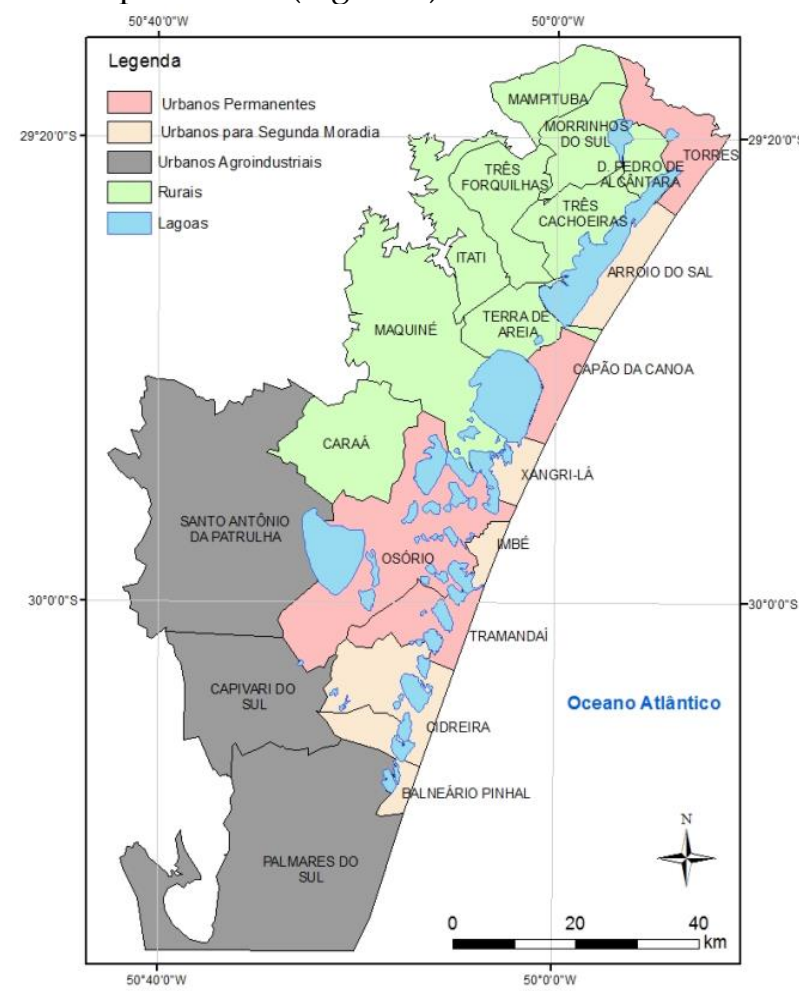

Figura 3: Classificação dos Municípios do Litoral Norte. Adaptado de Fujimoto et al., 2005.

Os municípios que se caracterizam por serem urbanos com população permanente são: Capão da Canoa (Fotografia 1), Osório, Tramandaí e Torres. Esses municípios são de médio porte apresentando características predominantemente urbanas, com população na faixa dos trinta a quarenta e cinco mil habitantes e um significativo número de domicílios ocupados o ano inteiro (Tabelas 1 e 2). São municípios antigos localizados junto à orla (planície marinha), e de seus territórios foram desmembrados muitos municípios com perfil atualmente de segunda residência (Figura 3). Constatou-se que, mesmo com as emancipações, esses municípios não perderam população, ao contrário, apresentaram incremento populacional decorrente de suas funções polarizadoras na região no tocante à concentração de investimentos públicos e privados (Fujimoto et al (2006).

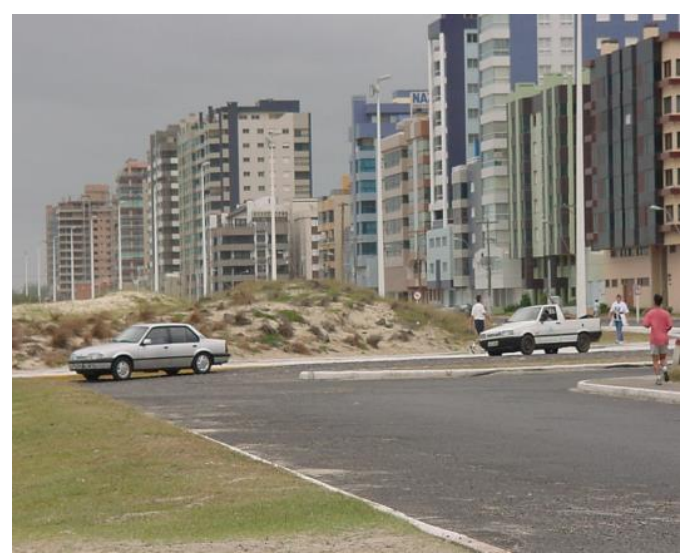

Fotografia 1: Verticalização urbana junto à orla do município de Capão da Canoa (2003).

Os municípios urbanos com perfil de segunda residência são: Arroio do Sal, Balneário Pinhal, Cidreira, Imbé e Xangri-lá. Esses municípios se caracterizam por serem de pequeno porte (na faixa de dez a vinte mil habitantes), estarem situados junto à orla (planície marinha) e terem sido áreas de balneários antes de sua criação. Esse grupo apresenta uma população predominantemente urbana $(95 \%)$, pois a maior concentração de domicílios ocorre na área urbana. No entanto, menos de $20 \%$ dos domicílios são ocupados permanentemente, comprovando que são municípios com perfil de segunda residência, com relevante aumento populacional nos meses de verão (Tabela 2).

Os municípios urbanos com população permanente ocupada com atividades agroindustriais são: Santo Antônio da Patrulha, Capivari do Sul e Palmares do Sul. São municípios que têm população predominantemente urbana, apesar das atividades econômicas predominantes estarem nas áreas rurais dos referidos municípios, e um número considerável de domicílios ocupados o ano inteiro (Tabelas 1 e 2). Eles se localizam nas áreas de planície lagunar, potencialmente adequada para a orizicultura e para o florestamento (indústria de celulose), associados às atividades industriais de beneficiamento desses cultivos, entre outras atividades industriais. 
Tabela 1: População Total, Urbana, Rural, Densidade Demográfica, Grau de Urbanização e Taxa de Crescimento dos Municípios do Litoral Norte - RS 2010.

\begin{tabular}{|c|c|c|c|c|c|c|c|c|c|}
\hline Municípios & $\begin{array}{l}\text { Area } \\
\left(\mathrm{Km}^{2}\right)\end{array}$ & $\begin{array}{c}\text { População } \\
\text { Total }\end{array}$ & $\begin{array}{r}\text { População } \\
\text { Urbana }\end{array}$ & $\%$ & $\begin{array}{c}\text { População } \\
\text { Rural }\end{array}$ & $\%$ & $\begin{array}{c}\text { Densidade } \\
\text { Demográfica }\end{array}$ & $\begin{array}{c}\text { Grau de } \\
\text { Urbanização (1) }\end{array}$ & $\begin{array}{c}\text { Taxa de } \\
\text { Crescimento } \\
\text { (2) }\end{array}$ \\
\hline Arroio do Sal & 120,912 & 7,740 & 7,509 & 97.02 & 231 & 2.98 & 64.01 & 97.02 & 3.92 \\
\hline Balneário Pinhal & 103,757 & 10,856 & 10,743 & 98.96 & 113 & 1.04 & 104.63 & 98.96 & 3.83 \\
\hline Capão da Canoa & 97,100 & 42,040 & 41,787 & 99.40 & 253 & 0.60 & 432.96 & 99.4 & 3.26 \\
\hline Capivari do Sul & 412,792 & 3,890 & 3,230 & 83.03 & 660 & 16.97 & 9.42 & 83.03 & 2.27 \\
\hline Caraá & 294,323 & 7,312 & 1,058 & 14.47 & 6,254 & 85.53 & 24.84 & 14.47 & 1.34 \\
\hline Cidreira & 245,885 & 12,668 & 12,260 & 96.77 & 408 & 3.23 & 51.52 & 96.77 & 3.6 \\
\hline D. Pedro de Alcântara & 78,158 & 2,550 & 741 & 29.05 & 1,809 & 70.95 & 32.63 & 29.05 & -0.33 \\
\hline Itati $^{*}$ & 206,910 & 2,584 & 212 & 8.20 & 2,372 & 91.80 & 12.49 & 8.20 & \\
\hline Imbé & 39,395 & 17,670 & 17,661 & 99.95 & 9 & 0.05 & 448.53 & 99.95 & 3.74 \\
\hline Mampituba & 157,920 & 3,003 & 568 & 18.91 & 2,435 & 81.09 & 18.91 & 18.95 & -0.36 \\
\hline Maquiné & 621,694 & 6,905 & 2,064 & 29.92 & 4,841 & 70.08 & 11.11 & 29.92 & -0.56 \\
\hline Morrinhos do Sul & 165,441 & 3,182 & 1,300 & 40.92 & 1,882 & 50.08 & 19.23 & 40.82 & -1.03 \\
\hline Osório & 663,552 & 40,906 & 37,917 & 92.70 & 2,989 & 7.30 & 61.65 & 92.7 & 1.26 \\
\hline Palmares do Sul & 949,209 & 10,969 & 9,803 & 89.37 & 1,166 & 10.63 & 11.56 & 89.37 & 0.11 \\
\hline St ${ }^{\circ}$. Antônio da Patrulha & $1.049,807$ & 39,685 & 28,114 & 70.84 & 11,571 & 29.16 & 37.80 & 70.84 & 0.74 \\
\hline Terra de Areia & 141,773 & 9,878 & 5,195 & 52.59 & 4,683 & 47.41 & 69.67 & 52.59 & -1.47 \\
\hline Torres & 160,565 & 34,656 & 33,340 & 96.20 & 1,316 & 3.80 & 215.84 & 96.20 & 1.16 \\
\hline Tramandaí & 144,408 & 41,585 & 40,577 & 97.59 & 1,008 & 2.41 & 287.97 & 97.59 & 2.99 \\
\hline Três Cachoeiras & 251,058 & 10,217 & 7,501 & 73.42 & 2,716 & 26.58 & 40.70 & 73.42 & 0.73 \\
\hline Três Forquilhas & 217,259 & 2,914 & 385 & 13.22 & 2,529 & 86.78 & 13.41 & 13.22 & -1.06 \\
\hline Xangrilá & 60,688 & 12,434 & 12,379 & 99.56 & 55 & 0.04 & 204.88 & 99.56 & 4.23 \\
\hline Litoral Norte & $6.182,606$ & 323,644 & 274,344 & 84.77 & 49,300 & 15.23 & 52.34 & 84.77 & 2.05 \\
\hline Rio Grande do Sul & $281.731,445$ & $10,693,929$ & $9,100,291$ & 85.10 & $1,593,638$ & 14.90 & 37.96 & 85.1 & 0.49 \\
\hline
\end{tabular}

Fonte: Censo Demográfico IBGE 2010. Município de Itati, emancipado em 1996, possui apenas o dado de população total: 2.836 habitantes. Na tabela este valor está incluído no dado do município de origem - Terra de Areia. (1) Igual ao quociente entre a população urbana e total, multiplicado por 100. (2) Refere-se ao período de 2000-2010. 
Tabela 2: Número de Domicílios Ocupados e Não Ocupados por Municípios do Litoral Norte do RS nos Anos de 2000 e 2001

\begin{tabular}{|c|c|c|c|c|c|c|c|c|c|c|}
\hline Municípios & $\begin{array}{l}\text { Total de } \\
\text { domicílios } \\
(2000)\end{array}$ & $\begin{array}{l}\text { № de } \\
\text { domicílios } \\
\text { ocupados } \\
\text { (2000) }\end{array}$ & $(\%)$ & $\begin{array}{l}\text { № de } \\
\text { domicílios } \\
\text { não } \\
\text { ocupados } \\
\quad(2000)\end{array}$ & $(\%)$ & $\begin{array}{l}\text { Total de } \\
\text { domicílios } \\
(2010)\end{array}$ & $\begin{array}{l}\text { № de } \\
\text { domicílios } \\
\text { ocupados } \\
\text { (2010) }\end{array}$ & $(\%)$ & $\begin{array}{l}\text { № de } \\
\text { domicílios } \\
\text { não } \\
\text { ocupados } \\
\quad(2010)\end{array}$ & $(\%)$ \\
\hline Arroio do Sal & 8.836 & 1.660 & 18,79 & 7.153 & 80,95 & 12.316 & 2.763 & 22,43 & 9.553 & 77,57 \\
\hline Balneário Pinhal & 12.112 & 2.268 & 18,72 & 9.844 & 81,27 & 15.037 & 3.786 & 25,18 & 11.251 & 74,82 \\
\hline Capão da Canoa & 28.889 & 8.935 & 30,93 & 19.954 & 69,07 & 40.302 & 13.660 & 33,90 & 26.642 & 66,10 \\
\hline Capivari do Sul & 1.131 & 946 & 83,65 & 184 & 16,27 & 1.557 & 1.279 & 82,15 & 278 & 17,85 \\
\hline Caraá & 2.584 & 1.987 & 76,90 & 597 & 23,10 & 4.098 & 2.575 & 62,84 & 1.523 & 37,16 \\
\hline Cidreira & 14.962 & 2.809 & 18,77 & 12.175 & 81,37 & 17.961 & 4.400 & 24,50 & 13.561 & 75,50 \\
\hline $\begin{array}{cc}\text { D. Pedro } & \text { de } \\
\text { Alcântara } & \end{array}$ & 987 & 838 & 84,90 & 149 & 15,10 & 1.170 & 995 & 81,62 & 215 & 18,38 \\
\hline Imbé & 20.271 & 3.751 & 18,50 & 16.520 & 81,50 & 25.500 & 6.027 & 23,64 & 19.473 & 76,36 \\
\hline Mampituba & 1.042 & 922 & 88,48 & 120 & 11,52 & 1.150 & 1.013 & 88,09 & 137 & 11,91 \\
\hline Maquiné & 2.895 & 2.186 & 75,51 & 709 & 24,49 & 3.267 & 2.329 & 71,29 & 938 & 28,71 \\
\hline Morrinhos do Sul & 1.195 & 1.088 & 91,05 & 107 & 8,95 & 1.399 & 1.159 & 82,84 & 240 & 17,16 \\
\hline Osório & 15.221 & 10.861 & 71,36 & 4.360 & 28,64 & 18.951 & 13.445 & 70,95 & 5.506 & 29,05 \\
\hline Palmares do Sul & 10.068 & 3.366 & 33,43 & 6.702 & 66,57 & 13.152 & 3.909 & 29,72 & 9.243 & 70,28 \\
\hline $\begin{array}{c}\text { Sto. Antônio da } \\
\text { Patrulha }\end{array}$ & 13.659 & 11.529 & 84,41 & 2.130 & 15,60 & 16.997 & 13.799 & 81,18 & 3.198 & 18,82 \\
\hline Terra de Areia & 4.547 & 3.407 & 74,93 & 1.140 & 25,07 & 4.667 & 3.328 & 71,31 & 1.339 & 28,69 \\
\hline Torres & 17.369 & 9.534 & 54,89 & 7.834 & 45,10 & 22.650 & 12.156 & 53,67 & 10.494 & 46,33 \\
\hline Tramandaí & 27.296 & 9.164 & 33,82 & 18.064 & 66,18 & 36.197 & 13.797 & 38,12 & 22.400 & 61,88 \\
\hline Três Cachoeiras & 3.176 & 2.833 & 89,20 & 343 & 10,80 & 3.844 & 3.431 & 89,26 & 413 & 10,74 \\
\hline Três Forquilhas & 1.182 & 991 & 83,84 & 191 & 16,16 & 1.287 & 1.015 & 78,86 & 272 & 21,14 \\
\hline Xangri-lá & 11.721 & 2.339 & 19,96 & 9.382 & 80,04 & 16.092 & 3.871 & 24,05 & 12.221 & 75,95 \\
\hline Litoral Norte & 187.028 & 79.214 & 42,35 & 107.814 & 57,64 & 257.594 & 108.697 & 42,20 & 148.897 & 57,80 \\
\hline
\end{tabular}

Fonte: Censo Demográfico IBGE de 2000 e 2010. 
Os municípios rurais são: Três Cachoeiras, Maquiné, Caraá, Morrinhos do Sul, Três Forquilhas, Mampituba, Dom Pedro de Alcântara e Itati. A maioria desses municípios foi emancipada na década de 1990, com exceção de Três Cachoeiras, que foi criado em 1988 (Figura 2). Esse grupo de municípios está localizado nas áreas de escarpa do Planalto Meridional, ele apresenta características predominantemente rurais, com estrutura fundiária baseada na pequena propriedade, com predominância da população rural, e sua economia está direcionada principalmente para o setor primário e, mais recentemente, também para o turismo ecológico (Tabela 1 e Fotografia 2).

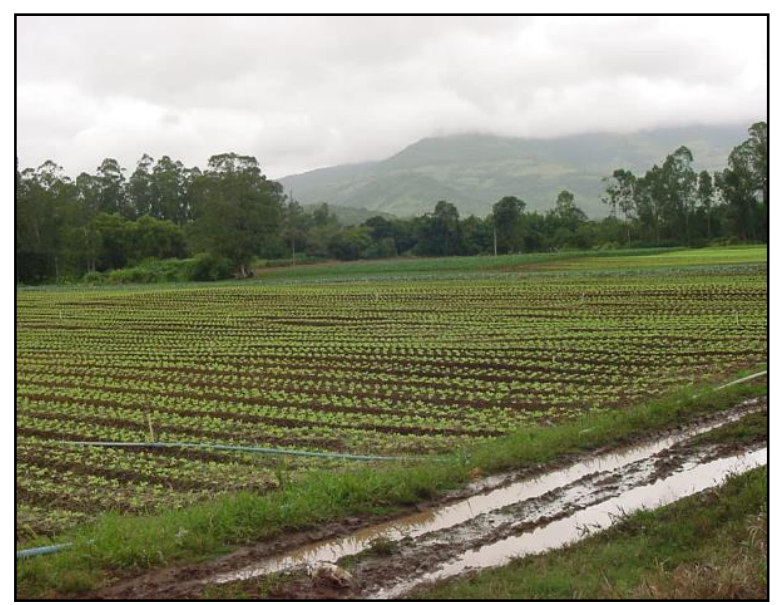

Fotografia 2: Plantio de hortaliças na área rural do município de Maquiné. Ao fundo as escarpas do Planalto Meridional (2003).

\subsection{Competições entre diferentes Tipos de Uso da Terra e os Principais Problemas Ambientais}

\section{Agricultura e urbanização}

Os problemas ambientais decorrentes da competição entre a agricultura e a urbanização ocorrem, predominantemente, nas planícies lagunares dentro do compartimento das Planícies de Terras Baixas Costeiras. A planície lagunar está localizada entre a planície marinha e a escarpa do Planalto Meridional. É uma área plana, homogênea, sem dissecação, onde predominam os processos de acumulação. Há um grande número de lagoas e canais, com variados tamanhos e profundidades que constituem a rede hidrográfica da planície lagunar. Próximo às lagoas pode-se constatar a presença de inúmeras áreas alagadas, regionalmente chamadas de banhados, em função do nível elevado do lençol freático em toda a Planície Costeira. A formação vegetal pioneira que coloniza a planície lagunar é constituída por herbáceas com grande diversidade em comparação com a planície marinha. Apresenta espécies adaptadas aos ambientes secos e alagados, além de espécies arbustivas e arbóreas (Figura 4).

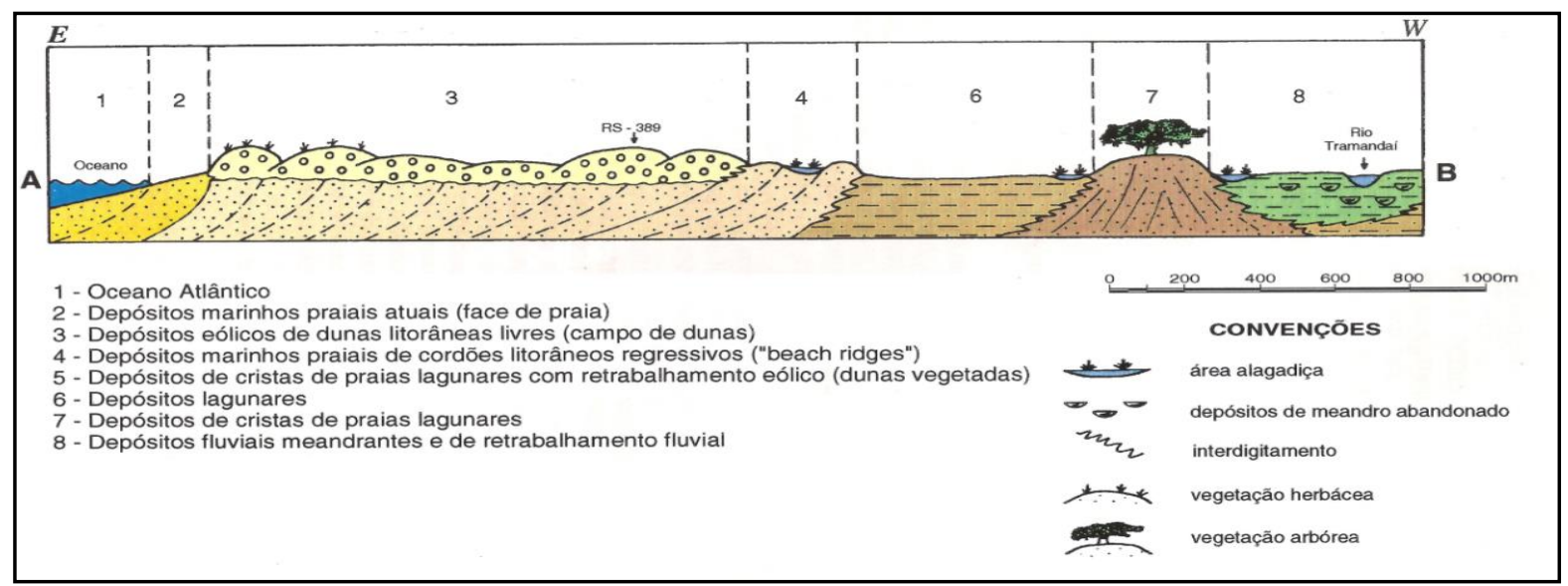

Figura 4: Perfil dos depósitos sedimentares do Litoral Norte do Rio Grande do Sul. Fonte: Jungblut (1995).

As planícies lagunares são áreas planas com grande disponibilidade de água em funções dos seus canais, rios e lagoas e, por isso, de grande potencial agropecuário. As principais atividades econômicas realizadas na planície lagunar são a pecuária de corte em seus campos de pastagens, as plantações de arroz em áreas alagadas, além 
das áreas de florestamento com a monocultura do pinus e do eucalipto.

As planícies lagunares, especialmente as mais próximas das áreas urbanizadas da planície marinha, até meados da década de 1990, apresentavam-se relativamente bem preservadas e com predomínio de atividades rurais. Mais recentemente, em função de sua qualidade ambiental e do esgotamento das áreas urbanas na planície marinha, tem surgido novos empreendimentos imobiliários (condomínios horizontais), ampliando a malha urbana dos municípios do Litoral Norte.

Além da retirada da cobertura vegetal e das alterações na morfologia original, a partir de cortes e da criação de superfícies planas para a construção de moradias, essas intervenções antrópicas alteram o fluxo das águas superficiais e subsuperficiais e o escoamento superficial, em função da dragagem das áreas alagadas e da impermeabilização da superfície. Outro problema gerado pela alteração no regime das águas, pela construção de moradias (resíduos domésticos) e de vias de acesso (estradas, ruas e caminhos) é a transferência de sedimentos e de outros materiais poluentes para os corpos d'água, afetando a comunidade aquática, reduzindo a sua produtividade e provocando contaminação dos solos e das águas.

De acordo com os dados da Fundação Estadual de Proteção Ambiental Henrique Luiz Roessler (FEPAM, 2005), as águas das lagoas Fortaleza, Cidreira, Rondinha, dos Quadros e Cerquinha são enquadradas na classe 1 , segundo a classificação estabelecida na Resolução $\mathrm{n}^{\mathrm{o}}$ 357/2005 do Conselho Nacional do Meio Ambiente (CONAMA). ${ }^{2}$ As lagoas de Itapeva e das Custódias, que apresentam ocupação em suas margens, foram classificadas na classe 2 . As águas do estuário da lagoa de Tramandaí enquadram-se na classe 3 que indica a presença significativa de coliformes fecais, provenientes do esgoto cloacal dos municípios de Tramandaí e Imbé. Nenhuma das lagoas costeiras analisadas pela FEPAM teve suas águas enquadradas na

\footnotetext{
${ }^{2}$ A Resolução 357/2005 do CONAMA dispõe sobre a qualificação do nível de qualidade apresentado pelos segmentos de corpos d'água em termos dos usos possíveis com segurança adequada, classificada em quatro classes para as águas do Território Nacional: classe especial, Classes 1, 2, 3 e 4.
}

classe especial, ou seja, águas de ótima qualidade.

Grande parte do esgoto produzido na planície lagunar não recebe tratamento adequado, tendo como destinação final fossas rudimentares ou sumidouros. Os municípios de Xangri-lá, Capão da Canoa e Arroio do Sul apresentam, respectivamente, 99,27\%, 99,5\% e $99,82 \%$ dos seus domicílios ligados à rede ou fossas, segundo o Censo Demográfico do IBGE (2010) (Gráfico 1). A situação é ainda mais grave porque suas águas são também utilizadas para a irrigação e para o abastecimento da população através de poços artesianos, podendo causar problemas de saúde à população.

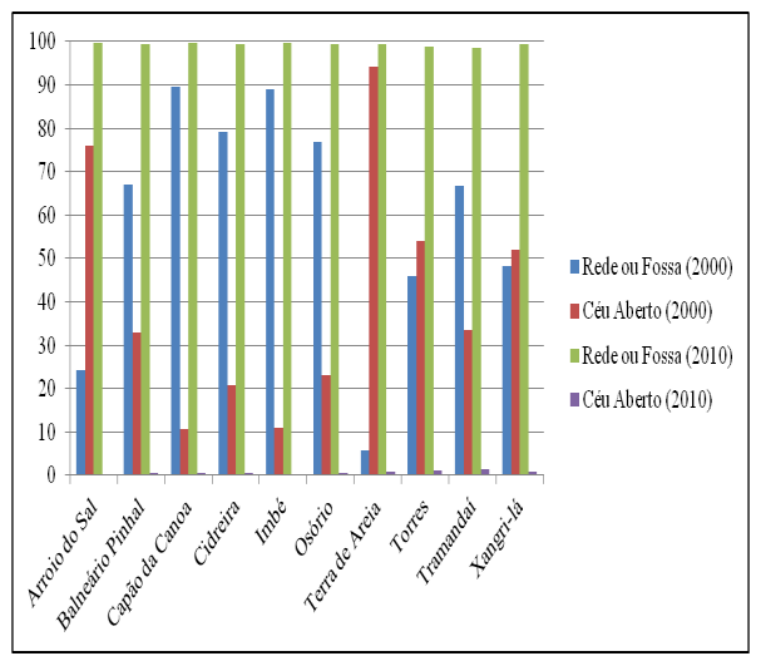

Gráfico 1: Destinação do Esgoto. Fontes: IBGE, Censos Demográficos 2000 e 2010.

Embora seja provável que o agricultor possa aumentar sua renda com a venda de suas terras para os empreendedores imobiliários, a expansão urbana desarticula a atividade agrícola e empobrece o pequeno produtor rural que migra para a cidade. As áreas que se tornam urbanas deixam, num processo irreversível, de fazer parte de terras cultiváveis, constituindo-se, portanto, em uma perda definitiva ao habitat natural da flora e da fauna nativa e de terras com alto valor agrícola.

Segundo Strohaecker (2001), a maior parte dos empreendimentos imobiliários é destinada à segunda residência para fins de lazer, principalmente para uso nos meses de verão, por veranistas de alto poder aquisitivo. Além das alterações na morfodinâmica original e demais consequências socioambientais, os condomínios provocam, ainda que parcialmente, a 
privatização do acesso às áreas de lagoas pela população em geral.

Em contraste com os condomínios horizontais de alto padrão surgem a ocupação espontânea de moradias irregulares em áreas alagadas nas proximidades dos condomínios, especialmente às margens das rodovias. Grande parte da população que habita essas moradias é proveniente das áreas rurais do entorno ou de outros municípios do estado que migraram para o Litoral Norte em busca de emprego no setor da construção civil e no setor de comércio e serviços (Strohaecker, 2001). Essas moradias são implantadas em locais que não possuem condições adequadas de saneamento e de infraestrutura básica e, além disso, a população residente apresenta significativa vulnerabilidade social e econômica.

\section{Urbanização e conservação}

Os problemas ambientais decorrentes da competição entre a urbanização e a conservação ocorrem tanto nas planícies lagunares quanto nas planícies marinhas, ambas no compartimento das Planícies de Terras Baixas Costeiras. No entanto, a urbanização é mais intensa no compartimento de planície marinha. Ao longo dessa planície que corresponde à orla da região, constata-se um processo de conurbação que expressa muito bem a conecção entre os municípios e, diante disso, a criação de uma unidade administrativa para fins de planejamento integrado para essa região, definida como Aglomeração Urbana (Figura 5).

A planície marinha está submetida, predominantemente, aos agentes praiais e eólicos, onde dominam os terraços marinhos e modelados eólicos. É marcada pela alternância de formas topográficas desde a faixa da praia até o limite da planície lagunar, sequência que pode ser descrita como:

[...] locais com pequenas elevações até 5,0 metros de altura constituídos por dunas frontais e dunas livres

(atuais) e cristas de cordões litorâneos regressivos, estas menos expressivas; depressões interdunas e cavas de cordões litorâneos regressivos e, finalmente, locais elevados de depósitos eólicos subatuais (paleodunas), com altitudes de até 10,0 metros

(Jungblut, 1995:05).

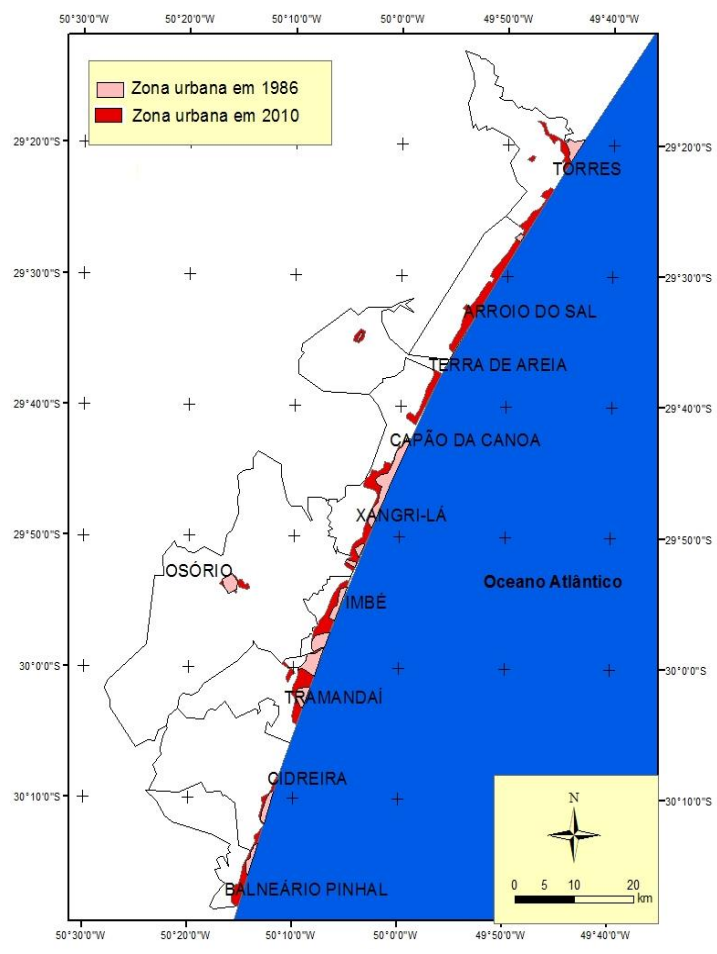

Figura 5: Mapa da Zona Urbana dos Municípios da Orla do Litoral Norte. Fonte: Kunst (2014).

A planície marinha possui pequenas lagoas situadas em depressões no mesmo nível ou abaixo do lençol freático. Nessas situações, formam áreas permanentemente inundadas com banhados que, em períodos de maior precipitação, transbordam e suas águas escoam, principalmente, para o oceano, através dos sangradouros. Os sangradouros são pequenos cursos de água que drenam a região de intercordões litorâneos em direção ao oceano, atuando na dinâmica das dunas e disponibilizando sedimentos para a deriva litorânea e, consequentemente, para o sistema praial e para os campos de dunas.

As áreas úmidas estão dispersas por toda a planície marinha e se constituem em ambientes ocupados por uma associação de vegetais, especialmente a presença de herbáceas. Junto à linha de praia predominam espécies halófilas adaptadas às condições salinas. Em função das diferentes feições encontradas na planície marinha, ocorrem, ainda, xerófilas associadas aos ambientes secos, hidrófilas e limnófilas em ambientes úmidos e alagados, respectivamente (Figura 4).

O Litoral Norte possui onze Unidades de Conservação (UCs), em sendo seis de proteção integral e cinco de uso sustentável, de acordo com o Sistema Nacional de Unidades de 
Conservação (SNUC). Entre os 21 municípios da região, somente Torres e Arroio do Sal possuem UCs na planície marinha, os quais correspondem a $0,019 \%$ e a $0,17 \%$ da área do município, respectivamente. As demais UCs estão localizadas, predominantemente, no compartimento do Planalto Meridional (Quadro 1).

\begin{tabular}{|c|c|c|c|c|}
\hline Unidades de Conservação & Área $\left(\mathbf{k m}^{2}\right)$ & Municípios & $\begin{array}{c}\text { Área do(s) } \\
\text { município(s) } \\
\left(\mathbf{k m}^{2}\right)\end{array}$ & $\begin{array}{c}\text { \% da Área } \\
\text { das UCs no(s) } \\
\text { município(s) }\end{array}$ \\
\hline $\begin{array}{l}\text { Refúgio da Vida Silvestre-Ilha dos } \\
\text { Lobos }^{1}\end{array}$ & 1,42 & Torres & \multirow[t]{4}{*}{160,565} & \multirow[t]{4}{*}{$0,019 \%$} \\
\hline Parque Estadual da Itapeva ${ }^{1}$ & 10 & Torres & & \\
\hline $\begin{array}{l}\text { Área de Proteção Ambiental Lagoa } \\
\text { da Itapeva }{ }^{2}\end{array}$ & 4,369 & Torres & & \\
\hline $\begin{array}{l}\text { Reserva Natural do Patrimônio } \\
\text { Natural Recanto do Robalo }{ }^{2}\end{array}$ & 0,0995 & Torres & & \\
\hline Parque Natural Municipal Tupancy ${ }^{1}$ & 0,21 & Arroio do Sal & 120,912 & $0,17 \%$ \\
\hline $\begin{array}{l}\text { Área de Proteção Ambiental Morro } \\
\text { de Osório }{ }^{2}\end{array}$ & 60,801 & Osório & 663,552 & $9,04 \%$ \\
\hline \multirow[t]{3}{*}{ Reserva Biológica da Serra Geral ${ }^{1}$} & \multirow[t]{3}{*}{48,457} & Terra de Areia & 141,773 & \multirow[t]{3}{*}{$0,46 \%$} \\
\hline & & Maquiné & 621,694 & \\
\hline & & Itati & 206,910 & \\
\hline $\begin{array}{l}\text { Reserva Particular do Patrimônio } \\
\text { Natural Mata do Professor Baptista }\end{array}$ & 0,092 & $\begin{array}{l}\text { Dom Pedro de } \\
\text { Alcântara }\end{array}$ & 78,158 & $0,11 \%$ \\
\hline \multirow{2}{*}{$\begin{array}{lll}\text { Estação } & \text { Ecológica } & \text { Estadual } \\
\text { Aratinga }^{1} & & \\
\end{array}$} & \multirow[t]{2}{*}{6} & Itati & 206,910 & \multirow[t]{2}{*}{$0,17 \%$} \\
\hline & & $\begin{array}{l}\text { São Francisco } \\
\text { de Paula }\end{array}$ & $3.272,948$ & \\
\hline \multirow[t]{4}{*}{$\begin{array}{l}\text { Área de Proteção Ambiental da Rota } \\
\text { do Sol }{ }^{2}\end{array}$} & \multirow[t]{4}{*}{546,705} & $\begin{array}{l}\text { Cambará do } \\
\qquad \mathrm{Sul}^{3}\end{array}$ & $1.208,647$ & \multirow[t]{4}{*}{$11,14 \%$} \\
\hline & & $\begin{array}{c}\text { São Francisco } \\
\text { de Paula }{ }^{3}\end{array}$ & $3.272,948$ & \\
\hline & & $\begin{array}{c}\text { Três } \\
\text { Forquilhas }\end{array}$ & 217,259 & \\
\hline & & Itati & 206,910 & \\
\hline $\begin{array}{llll}\text { Reserva } & \text { Biológica } & \text { da } & \text { Mata } \\
\text { Paludosa }^{1} & & & \\
\end{array}$ & 2,71 & Itati & 206,910 & $1,30 \%$ \\
\hline Total & 680,863 & 10 municípios & $6.692,409$ & $10,17 \%$ \\
\hline
\end{tabular}

Quadro 1: Unidades de Conservação do Litoral Norte do Rio Grande do Sul.

Fonte: http://www.fepam.rs.gov.br/qualidade/bacia tramandai.asp acessado em 20 de janeiro de 2015 e Castro \& Mello (2013). Ob.: ${ }^{1}$ UCs de proteção integral e ${ }^{2}$ UCs de uso sustentável. ${ }^{3}$ Não pertence a Região do Litoral Norte do RS.

A intensa expansão urbana e a pressão imobiliária em busca de novos empreendimentos tem agravado a situação das UCS em função da ocupação na área de entorno. Em muitas situações, são moradias irregulares sem
Além disso, as UCs possuem grandes carências de infraestrutura, manutenção e fiscalização. Muitas delas sofrem com a falta de sedes administrativas, equipamentos de segurança, veículos para a fiscalização, recursos humanos e demais itens indispensáveis para uma boa gestão e planejamento. 
apresentam concentração longitudinal à orla marítima e lacustre, principalmente no período de verão. $O$ intenso processo de urbanização neste compartimento provocou a quase total eliminação dos diferentes ecossistemas através da impermeabilização do solo, da destruição dos campos de dunas e dos sangradouros, do assoreamento das áreas de banhado, além da poluição das águas superficiais e do comprometimento da balneabilidade de vários segmentos de praia, conforme descritos nos trabalhos de Farion et al (2005); Strohaecker (2006); Gruber et al. (2011), Kunst (2014), entre outros. (Fotografia 4).

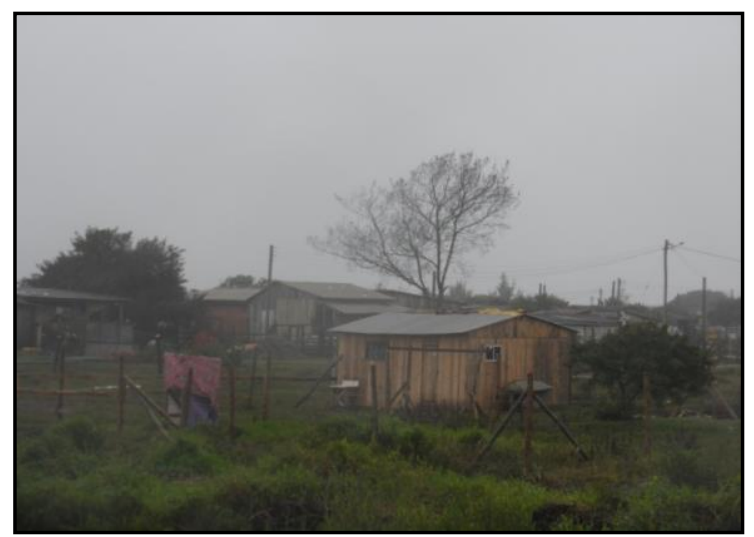

Fotografia 3: Ocupação informal nas planícies lagunares suscetíveis aos processos de inundação no município de Xangri-lá (2013).

Os processos de inundação e alagamentos são frequentes nas áreas urbanas em função da dificuldade de escoamento das águas superficiais em decorrência da impermeabilização e das modificações na rede de drenagem. Os processos de inundação e alagamentos ocorrem tanto nos setores urbanos mais valorizados economicamente quanto nos setores urbanos de ocupação permanente com carência de infraestrutura e informalidade na obtenção da moradia. Nesses últimos, a ocupação urbana ocorre em áreas suscetíveis aos processos de inundação, como em áreas de banhados nos fundos de loteamentos antigos.

Grande parte dos municípios do Litoral Norte da Orla Gaúcha não possui rede coletora de esgoto cloacal e nem estações de tratamento de esgoto. Um número significativo de domicílios utiliza fossas sépticas ou rudimentares que, por vezes, contaminam os corpos hídricos e o lençol freático. A contaminação das águas subterrâneas pode ser agravada devido à abertura indiscriminada de poços artesianos para abastecimento na região, comprometendo a balneabilidade das praias, das lagoas e a saúde da população (Basso e Pizzato, 2011).

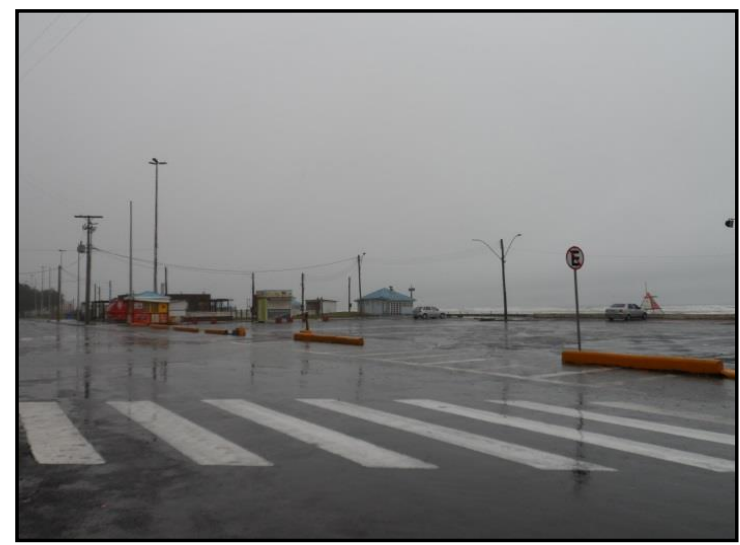

Fotografia 4: Eliminação das dunas frontais para instalação de estruturas para os veranistas na orla do município de Capão da Canoa (2014).

A destinação dos resíduos sólidos é outro grande problema que agrava a contaminação dos solos e das águas superficiais e a balneabilidade das praiais. A maioria dos municípios possui sistema de coleta de lixo, porém grande parte não implantou um sistema de coleta seletiva. Além disso, os resíduos sólidos são, na maioria, depositados em lixões a céu aberto, em função da falta de locais apropriados para a construção de aterros sanitários, pois as planícies costeiras são terrenos baixos e permeáveis com lençol de água aflorante e sujeitos constantemente à dinâmica eólica.

A retirada das dunas frontais para a construção de moradias, calçadões ou ruas intensifica a erosão e os efeitos das marés meteorológicas (ressacas de inverno) na praia, ampliando os prejuízos materiais (Villwock e Tomazelli, 1995).

\section{Agricultura e Conservação}

As áreas referentes à Unidade do Planalto Basáltico (representadas pelas encostas, morros e colinas) possuem cobertura vegetal do tipo Floresta Ombrófila Densa e vegetação secundária. Elas são constituídas de pequenas propriedades rurais onde se desenvolvem algumas culturas anuais como o milho e o feijão e também o cultivo da banana, do abacaxi e de pastagens naturais. Nas encostas dos morros são realizadas, por vezes, atividades de extração de 
produtos florestais (palmito, samambaia-preta, etc).

As propriedades que ocupam a Unidade de Planície de Terras Baixas Costeiras, predominantemente no compartimento de planície lagunar, possuem cobertura vegetal de mata galeria bastante devastada ao longo dos cursos d'água e pequenas áreas de florestas de terras baixas preservadas, além da vegetação típica de áreas alagadas (banhados). As principais atividades dessa região são a pecuária de corte, o gado leiteiro, o plantio da mandioca, a pesca e, em menor escala, o cultivo de olerículas e o plantio de arroz irrigado.

Embora toda a planície lagunar apresente-se basicamente como uma área plana com solos bastante arenosos, pode-se fazer uma diferenciação com relação ao uso da terra dentro das feições de relevo identificadas na planície lagunar. As planícies lagunares com cordões arenosos, devido à sua formação deposicional eólica, possuem solos incipientes em sua formação, com teores de umidade muito baixos. Estas características dificultam o cultivo de determinados produtos que requerem solos com relativa qualidade para a produção agrícola. Neste caso, observa-se que esses compartimentos são utilizados praticamente para a criação de pecuária de corte, gado leiteiro e pequenas roças de mandioca e de milho, além de extração de areia para uso comercial. Enquanto que nas planícies lagunares com deposição de origem fluvial e/ou lacustre são cultivados olerículas e arroz irrigado. $\mathrm{Na}$ maioria das propriedades rurais, o cultivo de arroz irrigado é alternado com a criação de gado de corte como estratégia de manejo do solo (Barcellos et al, 2004).

Entre os principais problemas ambientais identificados na área rural dos municípios do Litoral Norte, podem-se citar:

i) Degradação da cobertura vegetal: a atividade extrativista de espécies nativas de uso ornamental (samambaia, orquídeas, bromeliáceas e xaxins) desenvolvida por pequenos agricultores familiares locais promove uma exploração excessiva deste recurso florestal. Convém destacar que a extração de produtos florestais é regulamentada pela legislação federal e estadual e que a fiscalização procura inibir práticas extrativistas de forte impacto. No entanto, segundo Gerhardt et al (2000), essas práticas são decorrência de um longo processo de empobrecimento de uma parte significativa dos pequenos agricultores familiares locais que, para agravar a situação, são confrontados pela ação de alguns atravessadores que dominam o comércio da samambaia-preta, impondo preços baixos aos"samambeiros" (agricultores e moradores que se dedicam à extração de samambaia-preta), obrigando-os a realizar uma intensa exploração das áreas de produção desta espécie de samambaia.

ii) Contaminação das águas superficiais: são constatados em praticamente toda a região problemas ligados ao uso de insumos químicos e agrotóxicos decorrentes da orizicultura, desenvolvida em grandes propriedades nas planícies costeiras, com predomínio de depósitos lagunares e fluviais. Na bacia hidrográfica do rio Maquiné, de acordo com levantamentos feitos em vários pontos de captação de águas do rio, foram encontrados níveis significativos de contaminação por metais pesados (Gerhardt et al, 2000). Tal contaminação é decorrente do intensivo manejo das áreas de várzeas existentes ao longo do rio Maquiné, principalmente pela produção de olerículas. Além desses efeitos de contaminação das águas, a eliminação da vegetação nas margens dos rios e o uso inadequado do solo contribuem para o agravamento dos fenômenos de erosão e assoreamento de rios e lagoas. Essa situação de poluição ambiental acarreta grave impacto social e ambiental na região, criando um grande impedimento ao desenvolvimento de atividades de grande potencial econômico, como o turismo ecológico, além de comprometer significativamente a atividade pesqueira. De acordo com os relatos dos moradores, ocorreu uma enorme diminuição na quantidade e na variedade de peixes nos últimos anos no rio Maquiné e nas lagoas costeiras. Muitos associam essa degradação ao uso de herbicidas, fungicidas ou inseticidas no manejo agrícola do arroz irrigado e de outras culturas. Importante destacar que a rede de drenagem que tem suas nascentes, na maioria, no topo do Planalto Meridional, possui como exutório as lagoas costeiras, bem como suas áreas de banhado ou o oceano.

iii) Retirada da cobertura vegetal e alterações na morfologia original: as explorações de pedreiras e de mineração de areia promovem a retirada da cobertura vegetal nativa e alteram a 
morfologia original dos morros e das planícies. A eliminação da cobertura vegetal nativa ocorre em uma área reconhecida pela UNESCO, desde 1992, como Reserva da Biosfera da Mata Atlântica. Em seguida, ocorrem modificações na morfologia a partir da elaboração de cortes e da criação de superfícies expostas ligadas à mineração. A modificação do relevo promove a criação, indução e intensificação ou modificação do comportamento nos processos geomorfológicos, gerando novos padrões de comportamento morfodinâmico (Moura, 2011). Em geral, rompe-se a dinâmica geomorfológica natural e intensificam-se os processos erosivos e deposicionais. As atividades agrícolas, particularmente aquelas desenvolvidas em pequenas propriedades junto à escarpa do Planalto Meridional, em terrenos com declividades acentuadas e sem uso de técnicas adequadas, têm promovido o desmatamento de importantes resquícios da Mata Atlântica e contribuído para o surgimento de processos erosivos e de degradação do solo.

Seguindo a tendência nacional e estadual, os municípios do Litoral Norte com população predominantemente rural apresentam taxas de crescimento menores em relação aos municípios com elevado grau de urbanização. Entre os nove municípios rurais, seis apresentam taxas de crescimento negativo de acordo com o censo demográfico (IBGE, 2010), que são: Dom Pedro de Alcântara (-0,33\%), Mampituba (-0,36\%), Maquiné $(-0,56 \%)$, Morrinhos do Sul $(-1,03 \%)$, Terra de Areia $(-1,47 \%)$ e Três Forquilhas ($1,06 \%)$.

\section{Considerações finais}

A região do Litoral Norte apresentou nos últimos anos transformações relevantes na sua dinâmica socioespacial determinadas, principalmente, pelas emancipações, urbanização e turismo sazonal. No entanto, essas transformações ocasionaram uma série de problemas para um ambiente caracterizado por ecossistemas diversificados e de grande suscetibilidade.

As relações sociedade-natureza ampliaram-se nos últimos anos, permitindo identificar mudanças no uso da terra que indicam que o processo é dominado por vários agentes, diversos padrões de usos, múltiplas respostas sociais, climáticas e ecológicas, em várias escalas têmporo-espaciais e com variadas consequências no espaço geográfico e nas relações sociais com a natureza (Moran, 2010). A competição pelo uso da terra desponta como um fenômeno relevante nas mudanças no uso da terra. O conflito entre urbanização e agricultura ou áreas de conservação sugere que a expansão urbana ocupará o lugar das terras cultivadas. Isso, provavelmente, ocorrerá em lugares onde, principalmente, existiam atividades agrícolas localizadas em planícies costeiras e em planícies fluviais. Nesse sentido, entende-se que, além dos lugares centrais serem preservados, as áreas agrícolas produtivas também merece atenção contra a pressão do crescimento urbano ou de outros tipos de uso da terra.

$\mathrm{O}$ crescimento e a consolidação da Aglomeração Urbana do Litoral Norte é uma tendência atual. Contudo, tal aglomeração resultou da conurbação, entre outros fatores, de centros urbanos distintos, contendo muitas características dos diferentes centros que existiam antes da integração. Essa característica adiciona um desafio significativo para a governança urbana coesa, dificultando as tentativas de um desenvolvimento regional coordenado e com manejo ambiental, incluindo as adaptações para as mudanças climáticas globais e as situações de risco socioambiental.

\section{Agradecimentos}

Os autores agradecem o apoio do Departamento de Geografia da Universidade Federal do Rio Grande do Sul (Brasil) e do Center for Global Change and Earth Observtions of the Michigan State University (USA).

\section{Referências}

ANGEL, S; PARENT, J; CIVCO, D. L. BLEI, A. e POTERE, D. The Dimensions of Global Urban Expansion: Estimates and Projections for all Countries, 2000-2050. Progress in Planning 75, 2011, 53-107p.

BARCELLOS, D. M.; CHAGAS, M. F.; FERNANDES, M. B.; FUJIMOTO, N. S. V. M.; MOREIRA, P. S.; MÜLLER, C. B.; VIANNA, M. e WEIMER, R. A. 
Comunidade Negra de Morro Alto: Historicidade, Identidade, Territorialidade. Porto Alegre: Editora da UFRGS, 2004.

BASSO, L. A. \& PIZZATO, F. A Qualidade da Água da bacia hidrográfica do Arroio do Salso, Porto Alegre - RS In: XIV Simpósio Brasileiro de Geografia Física Aplicada, 2011, Dourados - MS. Anais... Dourados: Universidade Federal Grande Dourados, 2011. v.1.12p.

BRASIL. Censo demográfico 2000. Rio de Janeiro: IBGE, 2000. Disponível em: http://www.ibge.gov.br. [Acesso em 21 de junho de 2011].

BRASIL. Censo demográfico 2010. Rio de Janeiro: IBGE, 2010. Disponível em: http://www.ibge.gov.br. [Acesso em 20 de janeiro de 2015].

BRASIL. Projeto Orla: subsídios para um projeto de gestão. Brasília: Ministério do Meio Ambiente - Secretaria do Patrimônio da União, 2004.

BRUNS, A. The Environmental Impacts of Megacities in the Coast. In: PELLING, M. and BLACKBURN, S. Megacities and the Coast. Routledge, Taylor \& Francis Group, London and New York, 2013, 2269p.

CHHABRA, A. e GEIST, H. Multiple Impacts of Land-Use/Cover Change. In: LAMBIN, E. F. \& GEIST, H. (orgs.) LandUse and Land-Cover Change: Local Processes and Global Impacts. Springer Berlin Heidelberg, New York, 2006, 71116p.

FARION, S.R.L.; STROHAECKER, T.M e FUJIMOTO, N.S. V. M Contribuição para o Programa de Manejo da Interação praia-duna para o município de Tramandaí-RS. In: II CONGRESSO BRASILEIRO DE OCEANOGRAFIA, 2005, Vitória, Anais... Vitória: Tec Art Editora, 2005.
FUJIMOTO, N. S. V. M. STROHAECKER, T. M.; GRUBER, N.S.; KUNST, A.V.; FERREIRA, A.H. Litoral Norte do Estado do Rio Grande do Sul: indicadores socioeconômicos e principais alterações ambientais. In: Desenvolvimento e Meio Ambiente, Curitiba: Editora da UFPR, $n$. 13, 2006, p. 99-124, jan./jun.

FUJIMOTO, N.S.V.M.; STROHAECKER, T.M.; KUNST, A.V.; FERREIRA, A.H. Uso e ocupação do solo no Litoral Norte do Estado do Rio Grande do Sul - Brasil. In: ENCONTRO DE GEOGRÁFOS DA AMÉRICA LATINA, 2005, São Paulo, Anais... São Paulo; Departamento de Geografia/FFLCH/USP, p. 5575-5591, 2005.

GERHARDT, C.H.; TRIAN, L.C.; GUTERREZ, L.M.; MAGALHÃES, R.G.; FERREIRA, L. O. \& MIGUEL, L.A. Caracterização do Meio Rural do Município de Maquiné - RS: Subsídios para um Desenvolvimento Rural Sustentável. Porto Alegre: Relatório de Pesquisa, Associação Ação Nascente Maquiné (ANAMA), Programa de PósGraduação em Desenvolvimento Rural (PGDR/UFRGS) e Prefeitura de Maquiné, 2000.

GRUBER, N. L. S.. Subsídios à gestão costeira: vulnerabilidades ambientais e aspectos legais para normativas de uso e ocupação. In: GRUBER, Nelson Luiz Sambaqui et. al.. Problematica de los ambientes costeros sur de Brasil, Uruguay y Argentina. Buenos Aires: Croquis, 2011.

JUNGBLUT, M. Solos do Município de Xangri-Lá, RS. Porto Alegre: CPRM, 1995. LEI 6.938/1981 (LEI ORDINÁRIA) 31/08/1981. Disponível em: http://www.planalto.gov.br/ccivil 03/leis/ L6938.htm. Acesso em 24/03/2013.

KUNST, A. V. Impactos Ambientais Urbanos nos Municípios do Litoral 
Norte da Orla Gaúcha. Dissertação de Mestrado em Geografia. Programa de Pós-Graduação em Geografia da Universidade Federal do Rio Grande do Sul, 2014.

LACERDA De L.D.; KREMER, H.H.; KJERFVE, B.; SALOMONS, W.; MARSCHALL CROSSLAND, J.I. e CROSSLAND, C.J. South American Basins: LOICZ global change assessment and synthesis of river catchment-coastal sea interaction and human dimension. LOICZ reports ans studies. LOICZ, Texel, the Netherland, 2002, № 21 .

LAMBIN, E.F. \& MEYFROIDT, P. Trends in Global Land-Use Competition. In: SETO, K.C. and REENBERG, A. Rethinking Global Land Use in an Urban Era. Strungmann Forum Reports, 2014, 1122p.

MORAES, A. C. R. Contribuições para a gestão da zona costeira do Brasil: elementos para uma geografia do litoral brasileiro. São Paulo: Hucitec/Edusp, 1999.

MORAN, E.F. Environmental Social Science: Human Environment Interactions and Sustainability. Malden, MA: Wiley-Blackwell, 2010.

MOURA, N.S.V. Estudos Geográficos com Ênfase na Geomorfologia: Questões Teóricas, Metodológicas, Mapeamentos e Aplicações em Estudos Ambientais. Brazilian Geographical Journal, Uberlândia, v. 2, 2011, 171-181p.

PARRY, M.L.; CANZIANI, J.P.; PALUTIKOF, P.J.; VAN DER LINDEN, P.J. and HANSON, C. E. (orgs.) Contribution of Working Group II to the Fourth Assessment Report of the Intergovernmental Panel on Climate Change. Cambridge, United Kingdom and New York, NY, 2007.
RIO GRANDE DO SUL. Aglomerações urbanas no Rio Grande do Sul. Porto Alegre: Secretaria do Planejamento Teritorial e Obras do Estado do Rio grande do Sul, 1992.

RIO GRANDE DO SUL. Atlas sócioeconômico do estado do Rio Grande do Sul. Porto Alegre: Secretaria da Coordenação e Planejamento do Estado do Rio Grande do Sul, 2002.

RIO GRANDE DO SUL. Atlas sócioeconômico do estado do Rio Grande do Sul. Porto Alegre: Secretaria da Coordenação e Planejamento do Estado do Rio Grande do Sul, 2014.

RIO GRANDE DO SUL. Diretrizes ambientais para o desenvolvimento dos municípios do litoral norte. Porto Alegre: Fepam/ Programa de Gerenciamento Costeiro, 2000. (Cadernos de Planejamento e Gestão Ambiental, v.1).

RIO GRANDE DO SUL. Índice social municipal ampliado para o Rio Grande do Sul (1991-1996). Porto Alegre: Secretaria da Coordenação e Planejamento do Estado do Rio Grande do Sul/Fundação de Economia e Estatística, 2000. (Série Documentos FEE, no 45).

RIO GRANDE DO SUL. Lei Complementar № 12.100, de 27 de maio de 2004. Diário Oficial do Estado do Rio Grande do Sul, Porto Alegre, 28 de maio de 2004.

SALOMONS, W.; KREMER, H.H. \& TURNER, K. The Catchment to Coast Continuum. In: CROSSLAND, C. J.; KREMER, H. H.; LINDEBOOM, H.J.; CROSSLAND, J.I.M.; TISSIER, M.D.A. Coastal Fluxes in the Anthropocene: The Land Ocean Interations in the Coastal Zone Project of the Internacional Geosphere-Biosphere Programme. Springer Berlin Heidelberg, New York, 2005, 145-200p. 
SNUC LEI № 9.985, de 18 de julho de 2000. http://ttp://www.brasil.gov.br/infraestrut ura/2011/12/parque-eolico-de-osorio-rs-eo-maior-daamerica-latina, acessado em 21/10/2014.

STROHAECKER, T. M. A Urbanização no Litoral Norte do Estado do Rio Grande do Sul: Contribuição para a Gestão Urbana Ambiental do Município de Capão da Canoa. Tese de Doutorado em Geociências. Programa de Pós-Graduação em Geociências da Universidade Federal do Rio Grande do Sul, 2007.

STROHAECKER, T. M. A produção do espaço no litoral norte: uma análise preliminar. In: VERDUM, R.; STROHAECKER, T. M. (Orgs.). Ensino de Geografia, planejamento ambiental, gestão territorial. Porto Alegre: Associação dos Geógrafos Brasileiros Seção Porto Alegre, 2001, p.114-119.

STROHAECKER, T. M.; FUJIMOTO, N. S. V. M.; FERREIRA, A. H. \& KUNST, A.V. Caracterização do uso e ocupação do solo dos municípios do litoral norte do estado do Rio Grande do Sul. In: Desenvolvimento e Meio Ambiente, Curitiba: Editora UFPR, n. 13, 2006, p. 7598, jan./jun.

VILLWOCK, J. A.; TOMAZELLI, L. J. Geologia costeira do Rio Grande do Sul. Notas Técnicas, Porto Alegre, Centro de Estudos de Geologia Costeira e Oceânica/ UFRGS, n. 8, 1995, 1-45p. 